\title{
Spatial and temporal distribution of the gastropod Heleobia australis in an eutrophic estuarine system suggests a metapopulation dynamics
}

\author{
Carlos Alejandro Echeverría ${ }^{1 *}$, Raquel A. F. Neves ${ }^{1}$, Leandro A. Pessoa1, Paulo C. Paiva ${ }^{2}$ \\ ${ }^{1}$ Coastal and Estuarine Research Laboratory (Laboratório de Pesquisas Costeiras e Estuarinas-LABCOEST), UFRJmar, CT, Federal \\ University of Rio de Janeiro, Rio de Janeiro, Brazil; *Corresponding Author: labcoest@gmail.com \\ ${ }^{2}$ Polychaeta Laboratory, Zoology Department, Institute of Biology, Federal Univeristy of Rio de Janeiro, Rio de Janeiro, Brazil
}

Received 19 March 2010; revised 20 April 2010; accepted 25 April 2010.

\begin{abstract}
Hydrobiidae is one of the most diverse taxa among limnic and estuarine mollusks. Patterns of spatial and seasonal distribution of Heleobia australis were studied in ten stations over two years, in the urban eutrophic bay of Guanabara, Rio de Janeiro, Brazil. Spatial dispersal strategies in adults of this species, analyzed in the laboratory, revealed three patterns: 1) mobility on soft sediments; 2) mobility on hard substrata; and 3) the ability to lift from the bottom to the surface, to again sink down. This facilitate species movement from one location to another by surface currents or attached to floating debris. Thus, individuals are able to escape from an impacted area and further re-colonize other patches after recovering from local impacts. The hypothesis of metapopulation dynamics (sourcesink) was analyzed. Two stations with high and constant numbers of individuals were grouped and tested as possible 'sources'. The number of specimens in the remaining stations was highly variable, even with the complete disappearance and posterior highly dense re-occurrence of the mollusk, whereby these were tested as possible 'sinks'. Results derived from nested ANOVA supported the hypothesis of metapopulation dynamics in the case of $\boldsymbol{H}$. australis adults, ex-pressed through opportunistic-species domination of a highly impacted estuarine system, such as Guanabara Bay.
\end{abstract}

Keywords: Metapopulation; Benthic Macrofauna; Population Dynamics; Heleobia Australis; Guanabara Bay

\section{INTRODUCTION}

The family Hydrobiidae contains the largest diversity among limnic and estuarine mollusks, wherein Heleobia australis is a dominant species in several degraded aquatic habitats [1], with a wide distribution in mixohaline environments [2], therein consuming deposited organic-material, including their own fecal pellets (autocoprophagy), especially when submitted to pronounced intra-specific competition [3]. This species is capable of re-settling on a soft-sediment surface, thereby acting as a bioturbator, as well as hard-substrata, besides being able to float away from the sediment itself by creating a gas bubble inside its shell. In this way, adults can temporarily enter the water column, whereat they are carried along by the tide and wind driven currents [4-7]. This dispersion strategy in adults, together with opportunistic behavior $[8,9]$, facilitates both escape from excessively stressful situations and invasion of fresh or unpopulated areas thereby attesting to the success of this species in polluted and highly impacted places.

The spatial and seasonal distribution of Heleobia australis were studied in ten stations over two years in Guanabara Bay, (Rio de Janeiro, Brazil), a highly eutrophic urban bay. Two different patterns were observed: 1) the number of individuals was high and constant in two of the sampling stations, whereas 2) in the remainder there was considerable variation, to the point of complete disappearance and posterior highly dense recurrence. These patterns suggest that adults of the species are able to very quickly re-colonize depopulated areas, thereby recovering from mayor impacting events. This gave rise to the proposal of testing a metapopulation dynamics hypothesis to explain temporal variations in distribution patterns. In a metapopulation model, patches or groups of the population persist on a balance between local extinction and colonization [10]. Metapopulation may conform to its classical concept, in which all the sub-populations have a realistic chance of becoming extinct, but in other cases 
there may be significant variation in either size or quality of the individual patches [11]. Thus, patches may be divided into sources (donor patches) and sinks (receiver patches) [12]. In this study, we considered as "colonization" within the metapopulation model, the reinvasion of depopulated areas by adult individuals [13] of $H$. australis, mainly due to its floating/sinking mechanism, thereby allowing for dispersal over relatively long distances, albeit subject to currents.

The studied area (Guanabara Bay, Figure 1) is a semi-enclosed water-body surrounded by large urban zones, and is characterized as one of the most degraded estuarine systems along the Brazilian coast $[14,15]$. The pollution is caused by untreated domestic sewage, besides incoming petroleum derivates and heavy metals, all of which accumulating in bottom sediments [16]. This accumulation substantially contributes to the disappearance, substitution or emergence of specific benthic in-vertebrates, an expression of population dynamics which can be used as environmental bio-indicators $[17,18]$.

Herein we propose using a source-sink metapopulation model to explain the success of the species Heleobia australis in a eutrophic and highly impacted estuarine system, supported by its own dispersal strategies, opportunistic behavior and spatial and temporal distribution.

\section{MATERIALS AND METHODS}

\subsection{Study Area}

This study was undertaken in Guanabara Bay (Figure 1), an urban bay located in Rio de Janeiro, Brazil $\left(22^{\circ} 40^{\prime}\right.$ and $23^{\circ} 00^{\prime} \mathrm{S} ; 43^{\circ} 00^{\prime}$ and $43^{\circ} 20^{\prime} \mathrm{W}$ ). Circulation herein is essentially induced by semi-diurnal tidal currents, with a complex interaction of cold saline water input from the central (deeper) channel on the rising tide, and the warmer freshwater discharged from the surrounding rivers $[14,16]$. As to pollution and water exchange, three macro-regions have been defined by [19]: 1—a southern area undergoing pronounced oceanic influence, close to the opening of the bay (outer sector corresponding to BG 02, BG 03 and BG 09; Figure 1); 2-an intermediary sector, with heavily polluted waters adjacent to an overpopulated island (Governador Island), (BG 10, BG 13, BG 14 and BG 18; Figure 1); the highest concentrations of sewage are located immediately south of this island, in waters close to the adjacent continent. 3-an inner sector, (BG 18, BG 25 and BG 28), with stations influenced by fringe mangroves, and presenting local peak concentrations of domestic and industrial pollutants, and recurring oil-leaks from the local petroleum industry. Several rivers which discharge into the bay receive huge

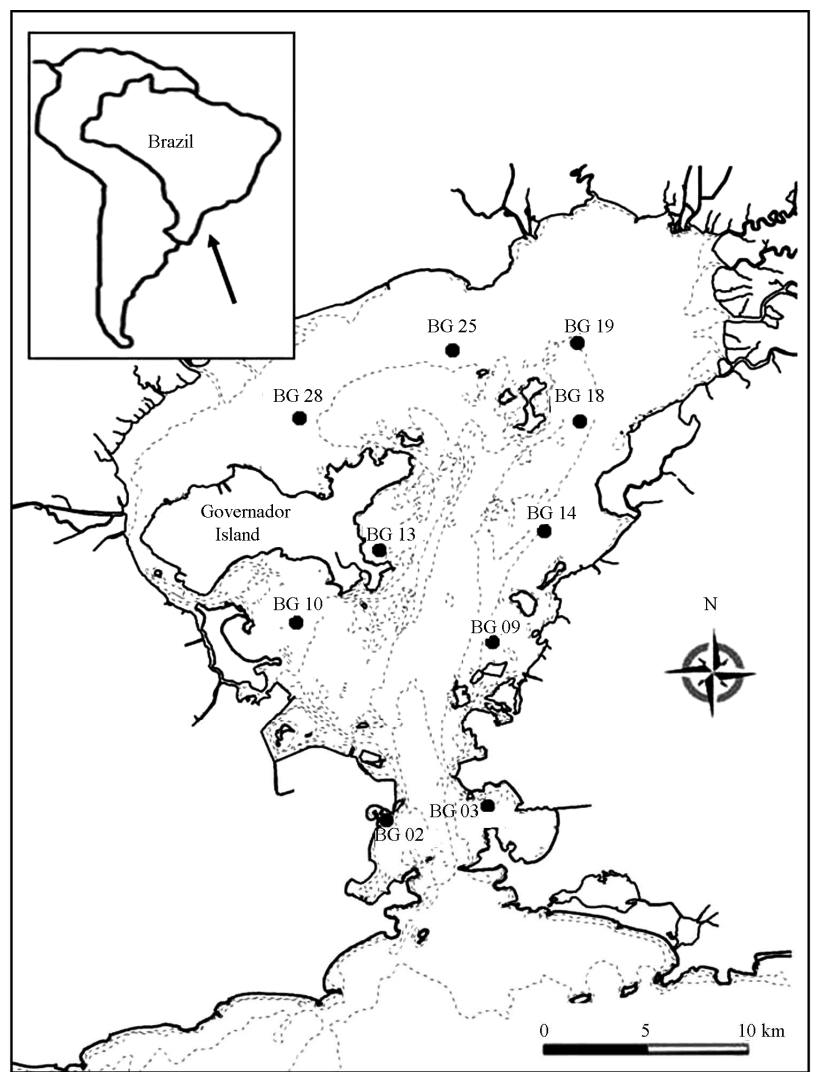

Figure 1. Guanabara Bay and indications of the surveyed stations $(\mathrm{BG})$.

amounts of domestic sewage and industrial inputs. These rivers directly discharge large amounts of suspended solids, organic matter, heavy metals and hydrocarbons $[16,20]$. The climate in the region is humid tropical with a seasonal pattern of heavy summer rains (December to March) and a comparatively dry winter (July-August [21]; Figure 2).

\subsection{Sampling}

In order to study spatial and seasonal distribution of the local $H$. australis population, samples were collected at ten stations distributed on an embayment gradient, at depths between 4 and 7 meters (Figure 1). A Gravity corer, capable of bottom-sampling $0.008 \mathrm{~m}^{-2}$ with minimum sediment disturbance, was developed for this study.

Stations were sampled in six surveys throughout two consecutive years, which were defined according to regional seasonal patterns (rainfall): Year 1: C1-(First survey), July, 2005-dry season; C2-December, 2005before the rainy season; C3-April, 2006-after the rainy season. Year 2: C4-July, 2006-dry season; C5- December, 2006-before the rainy season; and C6- April, 2007—after the rainy season (Figure 2; [21]). All sam- 


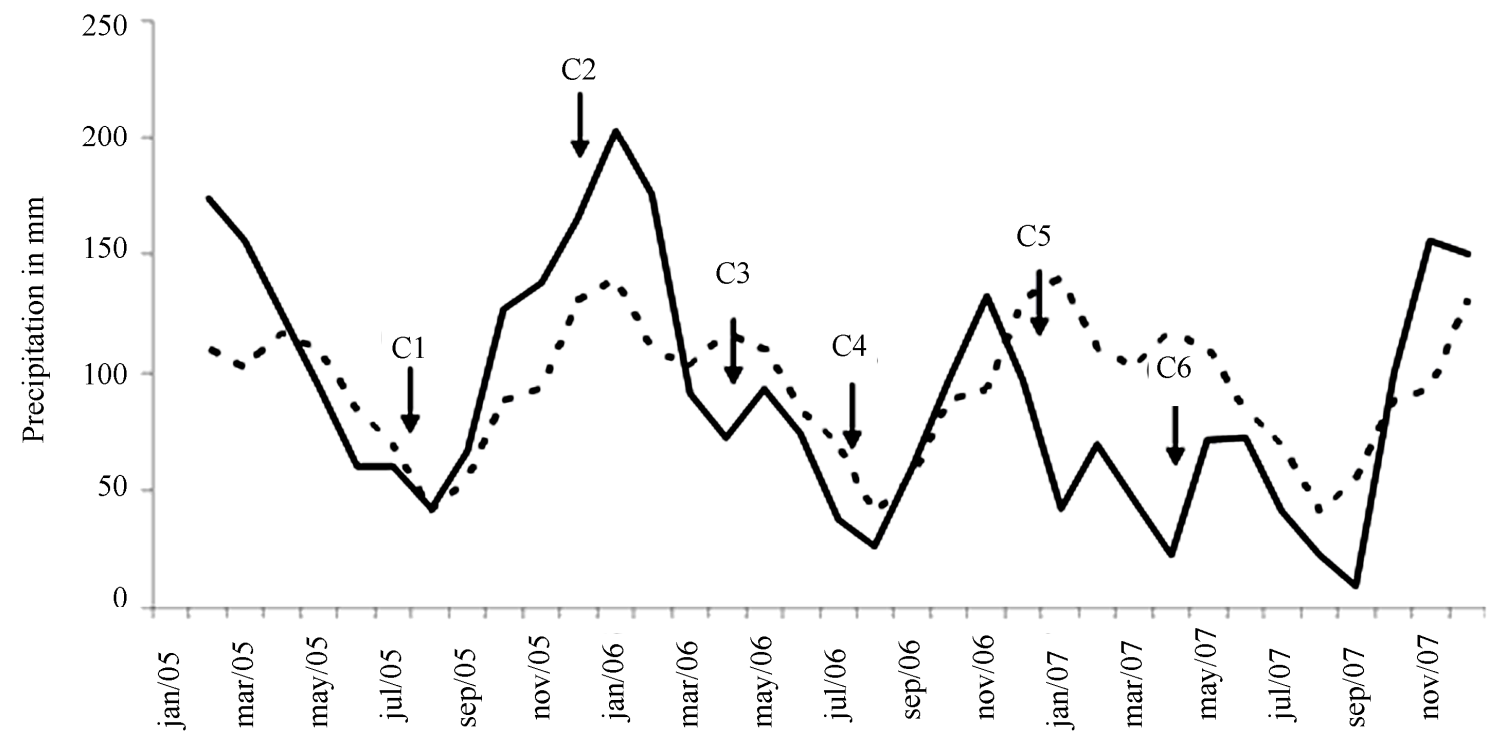

Figure 2. Historic mean-normal 61-90-(dotted line) and monthly accumulated rainfall (continuous line) in Rio de Janeiro, during the study. Surveys are shown by C1,C2,C3,C4,C5,C6. (modified from INMET, 2005-2007).

pling was carried out using the Research aluminium boat "Sizígia", from the Laboratório de Pesquisas Costeiras e Estuarinas (LABCOEST-UFRJmar-UFRJ).

Sediments of the seven inner and intermediate stations are predominantly silt-clay, where the Gravity corer per-formed satisfactorily. Of the remainder, two are located in sandy bottom sites (BG 02 and BG 03) and one (BG 09) a mixture of fine sand and clay [22]. The latter three stations were sampled by divers using a Gravity-like corer. Ten replicates were taken for each station per survey. Samples were sieved through a $0.5 \mathrm{~mm}$ mesh. Specimens were fixed and preserved in alcohol $70 \%$ for posterior analysis.

\subsection{Laboratory Experiment}

Heleobia australis adults were collected with a van Veen grab at station BG 10 (an intermediary station; Figure 1), in order to observe dispersal strategies and tolerance to hypoxic/anoxic bottoms. Specimens were maintained in aquaria with sea water and sediment collected from the very sampling station in the bay, both with and without continued aeration (aquarium-pump system). At least 30 specimens were monitored in both treatments their behavior and relative mortality being observed daily and weekly, respectively, during 30 days. Three dispersal strategies were taken into consideration, viz., mobility on the soft-sediment surface, flotation through the water column and mobility on hard substrata. The mortality rate was estimated by sampling approximately $40 \mathrm{ml}$ of sediment from each aquarium. After stabilization in a Petri dish for ten minutes, moving (living) and non- moving (dead) specimens were counted under a stereoscopic microscope.

In order to assess the hypothesis of long distance dispersal through adult flotation, a $30 \mathrm{~cm}$ diameter surface net with a $0.5 \mathrm{~mm}$ mesh was towed by the research boat "Sizígia", for five minutes in the area of source station BG 10 (Figure 1). The net was designed mainly for water surface sampling, with half of the opening out of the water. Organisms collected were transported to the laboratory and observed in Petry dishes for at least 12 hours, so as to check whether they were alive and in adequate conditions to colonize fresh areas.

A metapopulation dynamics model was proposed to assess temporal distribution of $H$. australis throughout the ten studied stations. The model was adapted to the manner in which specimens were considered able to "colonize" empty patches, and their way of shifting from the source patches, and was chosen as a way of explaining the observed patterns of rapid re-colonization with dense populations in previously empty patches in the bay. Source and sink patches were selected by sampling stations, taking into consideration the diverse observed patterns in density variation. Highly variable stations were assigned to sink patches, i.e., spots where either population densities were mainly maintained by the input of specimens from other areas, or areas that showed a local disappearance of the mollusk, probably due to the lengthy duration of anoxic bottom water events. Stations with constantly high densities were assigned to sources, i.e., sites propitious for maintaining an extremely high population, and thus scatter individuals to other areas in the bay. 


\subsection{Data Analysis}

Population data were $\log$-transformed $(\log (\mathrm{x}+1))$ before statistical analysis [23]. Temporal and spatial variation in species density were tested by means of variance analysis (Two-way ANOVA), considering as fixed factors sampling stations and survey period, and as dependent variables, the number of individuals per square meter in each sample. Density data were calculated using the average of the ten replicate corers expressed per square. In order to test the metapopulation hypothesis, two sampling stations were considered as possible 'sources', due to their high densities and low variability over time, viz., BG 10 and BG 28 (Figure 1). The other seven were assigned as 'sinks', mainly due to their high density variation over time, even, according to surveys, reaching the point of local extinction followed by recovery. Stations BG 02, BG 03 and BG 09 were excluded from statistical analyses, due to the lack of specimens in several surveys. In order to test the hypothesis of a metapopulation model, data were submitted to mixed-model ANOVA [24-27], with two fixed orthogonal factors, areas with two levels (source and sink) and time with 6 levels (each survey), besides stations as a random nested factor within areas.

\section{RESULTS}

\subsection{Spatial and Temporal Variation in Population Densities}

Population densities throughout the bay increased (Figure 4) after the rainy season (C3 and C6; Figure 2). These differences in $H$. australis abundance were highly significant, both in space and time, $\mathrm{p}<0,001$ (Figure 4).

Population densities followed three distinguishable patterns (Figure 3): 1) stations with constant and high numbers of $H$. australis throughout all the studied period (BG 10 and BG 28); 2) those with highly variable numbers of the mollusk, and even with peaks of abundance (BG 13) and local disappearance (BG 13 and BG 19, C3) and: 3) those mainly without the species, but with episodic events of occurrence, even in considerable numbers (BG 02, BG 03 and BG 09, C2, C3 and C6).

These patterns gave to understand that densities were liable to change in a very quick and extensive manner throughout the stations, thereby implying the re-colonization capacity of the species. From observations, metapopulation dynamics is thereby suggested as an adaptation procedure for its survival in extremely impacted
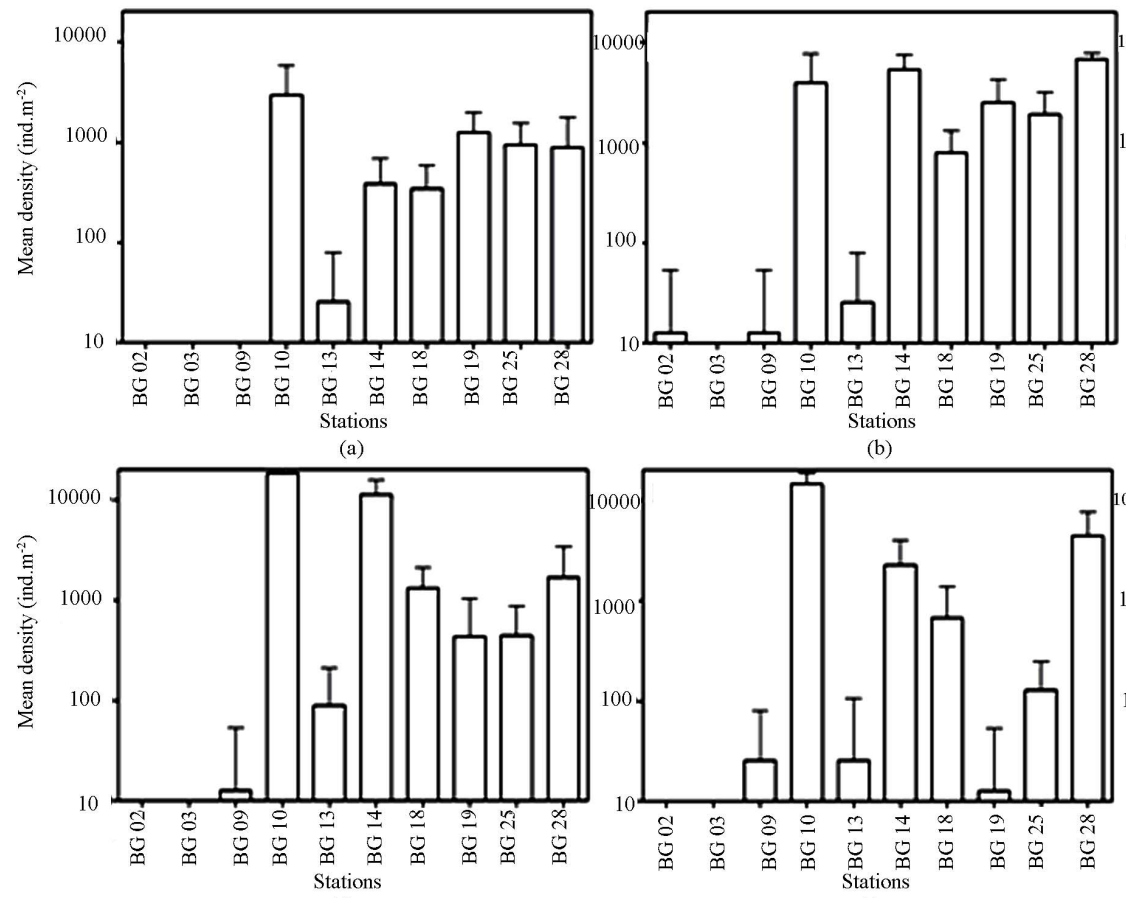

(d)

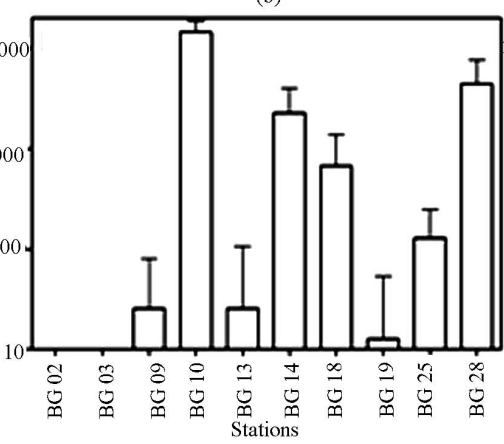

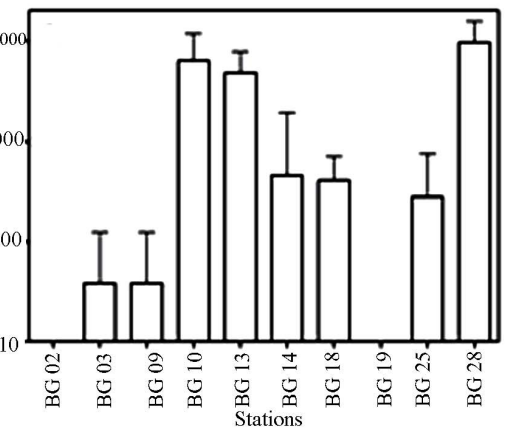

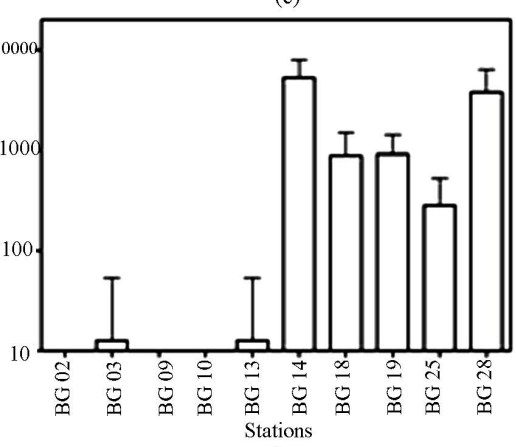

Figure 3. Mean density (Ind. $\mathrm{m}^{-2}$; Logarithmic scale) of Heleobia australis in the sampling stations (BG 02, BG 03, BG 09, BG 10, BG 13, BG 14, BG 18, BG19, BG 25 and BG 28) for the surveyed period. a) C1, July/2005, dry season; b) C2, December/2005, before the rainy season; c) C3, April/2006, after the rainy season; d) C4, July/2006, dry season; e) C5, December/2006, before the rainy season; f) C6, April/2007, after the rainy season. 
environments, evident as a notable instance of opportunistic behavior.

In order to test this hypothesis, stations with continuous high densities (BG 10 and BG 28) were selected as potential source-patches (Figure 4(a)), whereas stations with significant temporal variations in densities were selected as potential sink-patches (Figure 4(b)). The remainder was excluded from analysis, mainly due to their low densities (too many zeros in the matrix).

A comparison between source and sink stations revealed significant temporal and spatial variation (Table 1). Temporal patterns were significantly different between the two types, as indicated by the interaction between time and areas (time $\times$ areas; Table 1). Source stations appear to act as large patches in the meta-population model, by constantly supplying individuals to smaller patches (sink stations). This confirms the possibility that $H$. australis adults may take part in metapopulation dynamics, through their capacity for relatively long distance loco-motion (see below) throughout
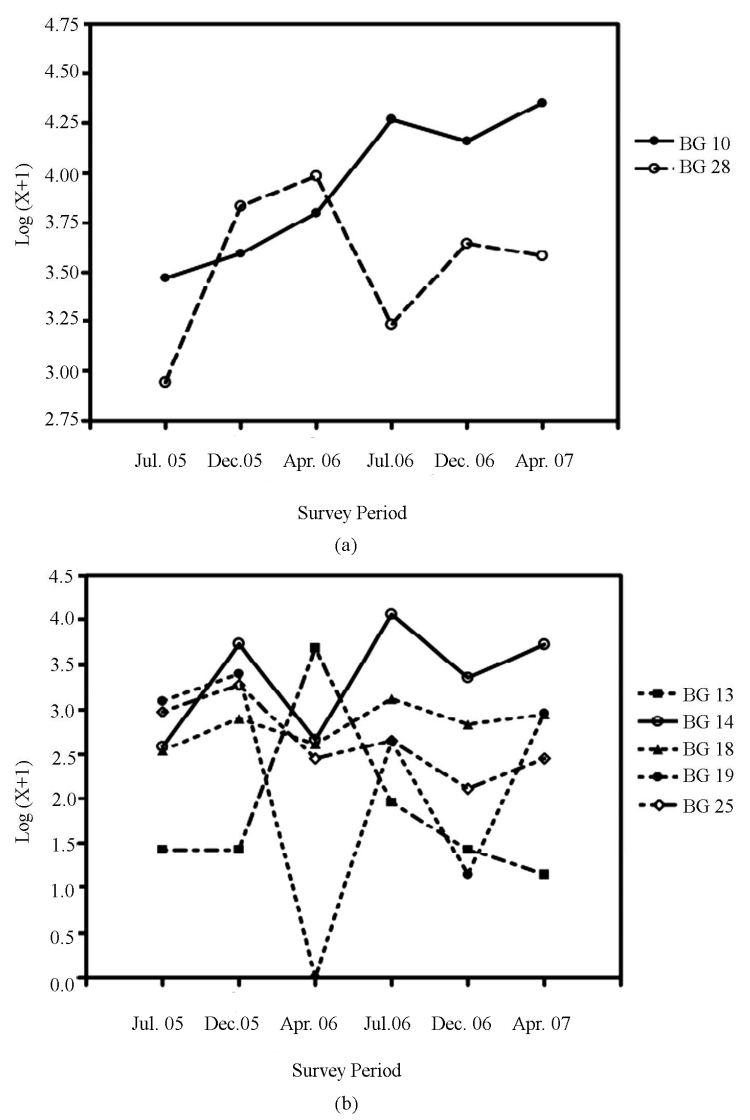

Figure 4. Mean density (Ind. $\mathrm{m}^{-2}$; log-linear scale) of Heleobia australis, grouped according the function of the patches; a) stations BG 10 and BG 28, source patches; b) Remaining stations, sink patches; except for BG 02, BG 03 and BG 09.
Table 1. Mixed-model ANOVA results, factors: time, arrears (source-sink), interaction (time $\times$ areas) and stations (areas).

\begin{tabular}{cccccc}
\hline Factor & S.S. & D.F. & MS. & F & P \\
\hline Time & 55.293 & 5 & 11.059 & 9.532 & 0.000 \\
Areas & 315.156 & 1 & 315.15 & 6.979 & 0.046 \\
Time $\times$ & 46.514 & 5 & 9.303 & 8.019 & 0.000 \\
Arear & & & & & \\
$\begin{array}{c}\text { Stations } \\
\text { Areas) }\end{array}$ & 225.794 & 5 & 45.159 & 38.926 & 0.000 \\
Error & 467.527 & 403 & 1.160 & & \\
\hline
\end{tabular}

an enclosed bay, as part of a species opportunistic strategy, thereby assuring success in an extremely impacted environment.

\subsection{Laboratory Experiments}

Under aquarium experimental conditions, with aeration lead to $100 \%$ mortality, whereas without all survived till the end of the experiment (30 days). This suggests that distribution at the outer stations could be limited, among other factors, by the concentration of dissolved oxygen in the water, Dispersal strategies were observed in both treatments, except for flotation, which was not observed under continued aeration.

The observed mobility patterns on soft-sediment, through leaving trails, is characteristic of a surface crawler, (paths; Figure 5(a)), and suggests depositfeeding behavior. Nevertheless, the species was also able to move over hard substrata, as demonstrated by their dispersal when adhering to the wall of an aquarium (Figure 3(b)). Adult flotation behavior may result in a relatively long distance and fast dispersion strategy, thereby facilitating the re-colonization of new or depopulated (post-impact) habitats (Figure 5(c)), thus implying a possible metapopulation scenario concerning the distribution pattern of a population in a semi-enclosed environment.

In five minutes of towing a surface net in the area of BG-10 station (considered as a possible source station), 60 alive and undamaged specimens of $H$. australis were collected, which were still alive after 12 hours of observation. Several specimens were also seen in situ attached to floating debris, as leaves, plastic bags, etc., all of which corroborating the possibility of long distance dispersal in adult specimens.

\section{DISCUSSION}

\subsection{Patterns of Spatial and Temporal Variation in Population Density}

The low densities observed at the outer stations could be related to environmental features, e.g. sediment type, since the predominant aspect was sandy bottoms un- 


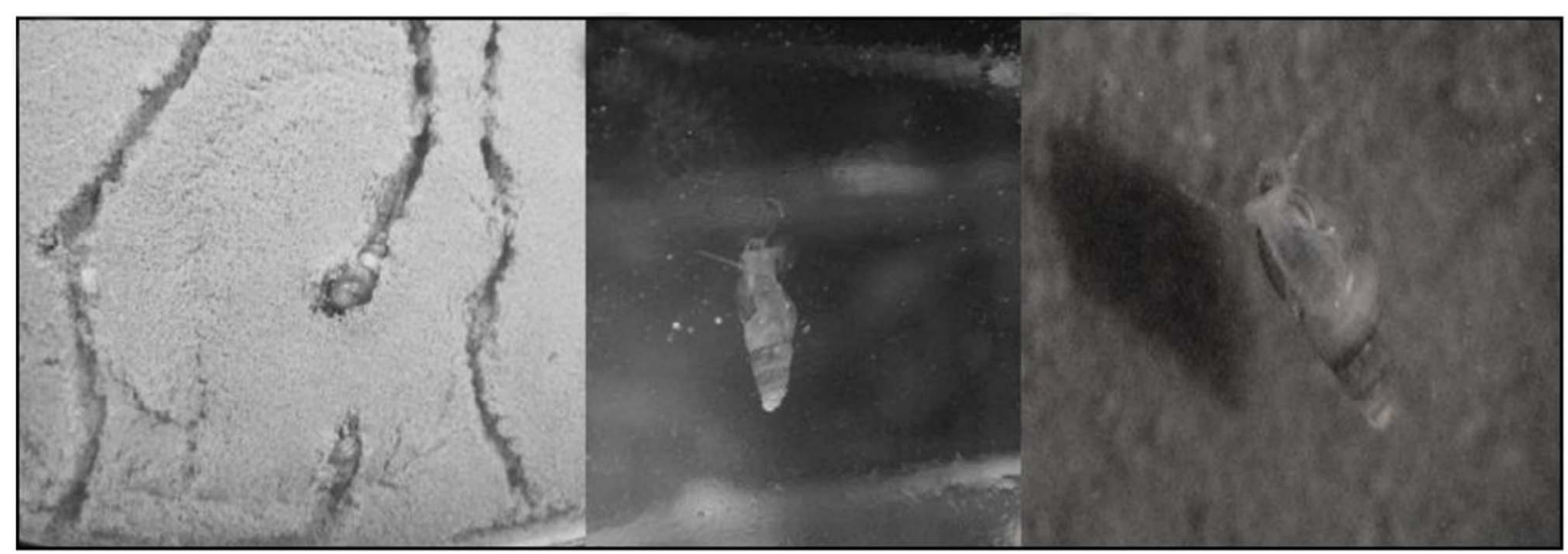

(a)

(b)

(c)

Figure 5. Dispersal strategies observed in the Heleobia australis during the manipulative experiments; a) mobility on a soft-sediment surface (trails); b) mobility on hard substrata (aquarium walls); c) flotation in the water column.

der-going strong oceanic water influence [22]. On the other hand, field measurements and laboratory experiments with Hydrobiidae in muddy and sandy habitats $[28,29]$ refuted the hypothesis of greater body size and density in the former [30]. Furthermore, when considering fine and coarse-grained sediments, no difference in growth rate was observed.

In our study, mortality was $100 \%$ in experimentally aerated aquariums, a possible indication that distribution, among other factors, could be limited by OD content, thereby implying that $H$. australis is a typical estuarine species, wherein bottom OD contents are likely to be lower. Furthermore, bottom water oxygen depletion over a long period could be an impacting factor, thereby probably causing the observed local disappearance of the mollusk at intermediate stations. Since, in this event, there were few dead organisms, and considering the species capacity of floating from the sediment into the water column, it is suggested that adult specimens are thereby able to avoid stressful environment situations.

Intermediate and inner sector stations are heavily affected by sewage pollution [31]. Oscillation in $H$. australis density in the latter was likely to be associated to variations in organic matter inputs and the resulting bottom water dissolved oxygen concentrations [32].

Higher densities of the mollusk in more degraded areas [16] is in agreement with opportunistic behavior, through the capacity in taking advantage of high organic metal levels and tolerating moderate or high habitat contamination, both in metals and organic compounds [33], besides a tolerance for hypoxic/anoxic bottom conditions [34]. Population increment after the rainy season (for example, stations C3 and C6; Figure 2) could be associated to increased continental input (organic matter) from the neighboring rivers [16] (Figure 4).

\subsection{Dispersion and Mobility}

The specimens used in lab experiments were collected from station BG 10, where bottom conditions are anoxic and concentrations of heavy metals, chlorophyll a and faecal coliforms high [35]. According to our experiments when dealing with aeration treatments, relatively higher levels of dissolved oxygen seemed to constitute a negative factor for this species. Aeration of originally anoxic sediments leads to the oxidation of reduced sulphur forms [36], usually, due to the high production of acids and a significant decrease in $\mathrm{pH}$ [37]. On studying the effects of acidification in freshwater gastropods, Okland [38] discovered that the group was completely absent in lakes with a $\mathrm{pH}$ lower than 5.2. The author mentioned the disappearance of three species during a $\mathrm{pH}$-reduction event (5.2-4.2), and considered that this was related to damage to their calcareous shells. Sediments with low $\mathrm{pH}$ seemed to be deleterious to $H$. australis under experimental conditions (microcosms). Thus, the increase in dissolved oxygen in bottom waters of impacted areas could have a negative effect on the mollusk. Nevertheless, under field conditions, individuals are capable of floating away from bottom areas with acid $\mathrm{pH}$ [39]. The opportunistic behavior in Heleobia australis is presumed through its adaptation to hypoxic/anoxic conditions, quick growth and colonization. Resiliency of benthic communities to short term hypoxic events depends on species composition, differential life cycle, reproduction period and pattern of larval dispersal [40]. Species mobility strategies are very important not only for self dispersal, but also for that of planktonic larvae, the observed adult flotation capability facilitating even wider 
dispersion $[41,42]$.

The dispersion tactics of $H$. australis give support to the proposed source-sink metapopulation strategy as observed in the eutrophic Guanabara Bay. Similar distribution patterns had been observed in Hydrobiidae species in Limfjord (Denmark) [34] and benthic communities in Botany Bay (Australia) [24]. The persistence of patches in a metapopulation depends on factors affecting extinction and colonization rates, such as inter-patch distances, species dispersal abilities and the number of patches [10]. The source-stations BG 10 and BG 28, and probably other patches in the bay, seem to sustain several sinkpopulation patches. The persistence of this metapopulation is dependent not only on the overall balance between local mortality and re-colonization, but also on the transport balance between source and sink areas. Patchiness in distribution of benthic species exists at different spatial scales [24,43]. In the case of $H$. australis, these patterns were observed by Neto and Lana [44] as small-scale aggregates (decimetric scale) within larger homogenous patches in Paranaguá Bay (Brazil).

Further studies on the dynamics of these populations of $H$. australis are necessary in order to establish an idea of transport intensity among patches and also to assess the spatial organization and flux between sink and source areas within the bay.

\section{ACKNOWLEDGEMENTS}

The present work is a result of the Project Environmental Evaluation of Guanabara Bay (Rio de Janeiro, Brazil), coordinated by CENPESPetrobrás. Authors wish to thank an anonymous reviewer for useful comments. To NS editors for aids on the preparation and submission of this Manuscript.

\section{REFERENCES}

[1] Senra, M.C.E. (2003) Análise preliminar e caracterização da malacofauna em sedimentos da Baía de Guanabara. Anuario do Instituto de Geociências da UFRJ, 26, 149151.

[2] Bemvenuti, C.E., Capitoli, R.R. and Gianuca, N.M. (1978) Estudos de ecologia bentônica na região estuarial da Lagoa dos Patos. II Distribuição quantitativa do macrobentos infralitoral. Atlantica, 3, 23-32.

[3] Lopez-Figueroa, F. and Niell, F.X. (1988) Feeding behavior of Hydrobia ulvae (Pennant) in microcosms. Journal of Experimental Marine Biology and Ecology, 114(2-3), 153-167.

[4] Little, C. and Nix, W. (1976) The burrowing and floating behavior of the gastropod Hydrobia ulvae. Estuarine, Coastal and Marine Science, 4(5), 537-544.

[5] Bemvenuti, C.E. (1998) Fundos não vegetados. In: Seeliger, U., Odebrecht, C. and Castello, J. Eds., Os ecossistemas costeiro e marinho do extremo sul do Brasil, Ecoscientia, Rio Grande, Brazil, 87-92.
[6] Norkko, J., Bonsdorff, E. and Norkko, A. (2000) Drifting algal mats as an alternative habitat for benthic invertebrates: Species specific responses to transient resource. Journal of Experimental Marine Biology and Ecology, 248(1), 79-104.

[7] Orvain, F. and Sauriau, P.G. (2002) Environmental and behavioural factors affecting activity in the intertidal gastropod Hydrobia ulvae. Journal of Experimental Marine Biology and Ecology, 272(2), 191-216.

[8] Lana, P.C. (1986) Macrofauna bêntica de fundos sublitorais não consolidados da Baía de Paranaguá (Paraná). Neritica, 1(3), 79-89.

[9] Bemvenuti, C.E., Cattaneo, A.S. and Netto, S.A. (1992) Características estruturais da macrofauna bentônica em dois pontos da região estuarial da Lagoa dos Patos, RS, Brasil. Atlantica, 14(4), 5-28.

[10] Stiling, P. (1996) Ecology: Theories and applications. 2nd Edition, Prentice-Hall Inc, New Jersey.

[11] Holyoak, M., Leibold, M.A. and Holt, R.D. (2005) Me-tacommunities: Spatial dynamics and ecological communities. University of Chicago Press, Chicago.

[12] Pulliam, H.R. (1988) Sources, sinks and population regulation. American Naturalist, 132(5), 652-661.

[13] Junkins, R., Kelaher, B. and Levinton, J. (2006) Contribution of adult oligochaete emigration and immigration in a dynamic soft-sediment community. Journal of Experimental Marine Biology and Ecology, 330(1), 208220.

[14] Amador, E.S. (1997) Baía de Guanabara e ecossistemas periféricos: Homem e natureza. Reporte Gráfica e Editora LTDA, Rio de Janeiro.

[15] Valentin, J.L., Tenenbaum, D.R., Bonecker, A.C.T., Bo-necker, S.L.C., Nogueira, C.R. and Villac, M.C. (1999) Osistema planctônico da Baía de Guanabara: Síntese do conhecimento. In: Silva, S.H.G. and Lavrado, H.P. Eds., Ecologia dos ecossistemas costeiros do estado do Rio de Janeiro, Série Oecologia Brasiliensis, Rio de Janeiro, 35-39.

[16] Kjerfve, B., Ribeiro, C.H.A., Dias, G.T.M., Filippo, A.M. and Quaresma, V.S. (1997) Oceanographic characteristics of an impacted coastal bay: Baía de Guanabara, Rio de Janeiro, Brazil. Continental Shelf Research, 17(13), 1609-1643.

[17] Underwood, A.J. (1991) Beyond BACI: Experimental designs for detecting human environmental impacts on temporal variations in natural populations. Australian Journal of Marine and Freshwater Research, 42(5), 569-587.

[18] Underwood, A.J. (1992) Beyond BACI:The detection of environmental impact on populations in the real, but variable, world. Journal of Experimental Marine Biology and Ecology, 161(2), 145-178.

[19] Wandeness, A.P., Mattos, M.A.R. and Nogueira, C.S.R. (1997) Copepoda (Crustacea) of Guanabara bay, R.J.I. specific composition. Brazilian Archives of Biology and Technology, 40, 377-381.

[20] Geraldes, M.C., Paula, A.H., Godoy, J.M. and Valeriano, C.M. (2006) $\mathrm{Pb}$ isotope signatures of sediments from Guanabara Bay, SE Brazil: Evidence for multiple anthro-pogenic sources. Journal of Geochemical Exploration, 88(1-3), 384-388.

[21] INMET. (2005-2007). Rain precipitation data of the re- 
gion and years of study, Meteorology National Institute. (Meteorology National Institute data center, RJ, BR) on-line. http://www.inmet.gov.br

[22] Quaresma, V.S., Dias, G.T.M. and Baptista Neto, J.A. (2000) Caracterização da ocorrência de padrões de sonar de varredura lateral e sísmica de alta freqüência $(3,5 \mathrm{e}$ $7,0 \mathrm{kHz}$ ) na porção sul da Baía de Guanabara-RJ. Brazilian Journal of Geophysics, 18(2), 201-214.

[23] Quinn, G.P. and Keough, M.J. (2003) Experimental design and data analysis for biologists. Cambridge University Press, Cambridge.

[24] Morrisey, D.J., Howitt, L., Underwood, A.J. and Stark, J.S. (1992) Spatial variation in soft-sediment benthos. Marine Ecology Progress Series, 81, 197-204.

[25] Sokal, R.R. and Rohlf, F.J. (1995) Biometry: The principles and practice of statistics in biological research. 3rd Edition, W. H. Freeman and Co, New York.

[26] Underwood, A.J. (1997) Experiments in ecology: Their logical design and interpretation using analysis of variance. Cambridge University Press, Cambridge.

[27] Paiva, P.C. (2001) Spatial and temporal variation of a nearshore benthic community in Southern Brazil: Implications for the design of monitoring programs. Estuarine, Coastal and Shelf Science, 52(4), 423-433.

[28] Forbes, V.E. and Lopez, G.R. (1990) The role of sediment type in growth and fecundity of mud snails (Hidrobiidae). Oecologia, 83, 53-61.

[29] Grudemo, J. and Bohlin, T. (2000) Effects of sediment type and intra- and interespecific competition on growth rate of the marine snails Hydrobia ulvae and Hydrobia ventrosa. Journal of Experimental Marine Biology and Ecology, 253, 115-127.

[30] Fish, J.D. and Fish, S. (1974) The breeding cycle and growth of Hydrobia ulvae in the Dovey Estuary. Journal of the Marine Biology Association UK, 54(3), 685-697.

[31] Paranhos, R., Pereira, A.P. and Mayr, L.M. (1998) Diel variability of water quality in a tropical polluted bay. Environmental Monitoring and Assessment, 50(2), 131-141.

[32] Mayr, L.M., Tenenbaum, D.R., Villac, M.C., Paranhos, R., Nogueira, C.R., Bonecker, S.L.C. and Bonecker, A.C.T. (1989) Hydrobiological characterization of Guanabara Bay. In: Magoon, O. and Neves, C. Eds., Coastlines of Brazil, American Society of Civil Engineers, New York, 124-138.

[33] Rakocinski, C.F., Brown, S.S., Gaston, G.R., Heard, R.W.,
Walker, W.W. and Summers, J.K. (2000) Species-abundance-biomass responses by estuarine macrobenthos to sediment chemical contamination. Journal of Aquatic Ecosystem Stress and Recovery, 7(3), 201-214.

[34] Fenchel, T. (1975) Factors determining the distribution patterns of mud snails (Hydrobiidae). Oecologia, 20(1), $1-17$.

[35] Lacerda, L.D., Souza, C.M.M. and Pestana, M.H.D. (1988) Geochemical distribution of $\mathrm{Cd}, \mathrm{Cu}, \mathrm{Cr}$ and $\mathrm{Pb}$ in sediments along the southeastern Brazilian coast. In: Seeliger, U., Lacerda, L.D. and Patchineelam, R. Eds., Metals in Coastal Environments of Latin America, Springer, Berlin, 86-89.

[36] Davis, A.P., Hao, O.J. and Chen, J.M. (1994) Kinetics of heavy metal reactions with ferrous sulphide. Chemosphere, 28(6), 1147-1164.

[37] Ivanov, M.V. (1983) Major fluxes of the global biogeo-chemical cycle of sulphur. In: Ivanov, M.V. and Freney, J.R. Eds., The Global Biogeochemical Sulphur Cycle, Wiley, Chichester, 449-463.

[38] Okland, J. (1992) Effects of acidic water on freshwater snails: Results from a study of 1000 lakes throughout Norway. Environmental Pollution, 78(1-3), 127-130.

[39] Bemvenuti, C.E., Rosa-Filho, J.S. and Elliot, M. (2003) Changes in soft-bottom macrobenthic assemblages after a sulphuric acid spill in the Harbour of Rio Grande (RS-Brazil). Brazilian Journal of Biology, 63(2), 183194.

[40] Rosenberg, R. (2001) Marine benthic faunal successional stages and related sedimentary activity. Scientia Marina, 65(2), 107-119.

[41] Santos, S.L. and Simon, J.L. (1980) Marine soft-bottom community establishment following annual defaunation: Larval or adult recruitment? Marine Ecology Progress Series, 2, 235-241.

[42] Little, C. (2000) The biology of soft shores and estuaries. Oxford University Press, New York.

[43] Thrush, S.F., Hewitt, J.E. and Pridmore, R.D. (1989) Patterns in the spatial arrangement of polychaetes and bivalves in intertidal sandflats. Marine Biology, 102(4), 529-535.

[44] Neto, A.S. and Lana, P.C. (1994) Effects of sediment disturbance on the structure of benthic fauna in a sub-tropical tidal creek of southeastern Brazil. Marine Ecology Progress Series, 106, 239-247. 